\title{
頸胸境界部食道癌の治療上の問題点とその対策
}

\author{
*藤田 博正，川原 英之 \\ 日高 正晴，吉松＼cjkstart博
}

\section{Surgical Treatment for the Carcinoma at the Boundary between the Superior Mediastinal and Cervical Segment of the Esophagus}

\author{
Hiromasa Fujita, M.D., Hideyuki Kawahara, M.D., \\ Masaharu Hidaka, M.D. and Hiroshi Yoshimatsu, M.D. \\ Department of Thoracic and Cardiovascular Surgery, University of Occupational and \\ Environmental Health, School of Medicine, Kitakyushu
}

The blunt dissection via partial sternectomy was carried out for four patients with carcinoma at the boundary between the superior mediastinal and cervical segment of the esophagus. This procedure must be devised to prevent recurrence in the thoracic lymph nodes, tracheal necrosis, bronchopneumonia followed by the short trachea and stenosis of the tracheal stoma.

As a new method, the laryngo-esophagectomy via the right thoracotomy and partial median sternotomy with some modifications was carried out. This devised surgical procedure seems to be an appropriate operative method for carcinoma of the esophagus in this location, because intrathoracic lymph nodes were able to be dissected and the trachea was protected from necrosis by preserving of the right bronchial artery and by covering with the muscle flap of the latissimus dorsi.

Key words : carcinoma between the superior mediastinal and cervical segment of the esophagus, blunt dissection of the esophagus, partial median sternotomy, Grillo's operation, muscle flap of the latissimus dorsi

\section{I .はじめに}

頸胸境界部食道癌に対する標準術式は，まだ 確立されておらず，種々の術式が試みられてい るのが現状である ${ }^{1)-5)}$ 。教室では頸胸境界部にあ つて気管に浸潤する進行食道癌に対し，胸骨上 $1 / 3$ 切除を加えた喉頭食道全摘術 (blunt dissection）をおこなってきたが，種々の問題点があ り，術式の再検討をせまられた。そこで，それ ら問題点に対処する一方法として，右開胸・胸 骨部分縦切開・喉頭食道全摘術にいくつかの術

${ }^{*}$ 産業医科大学第 2 外科学教室
式上の工夫を加えた手術法を試みたので報告す る。

\section{II ．検索対象}

1980年から1984年までの 5 年間に教室で経験 した食道癌は47例で，その42例（89\%）が切除 された。頸胸境界部食道癌は 8 例で， 6 例に切 除術が，2例にバイパス術がおこなわれた。癌 の占居部位と術式の関係をみると, 頸部食道(以 下, $\mathrm{Ce}$ と略す) >胸部上部食道 (以下, Iu と略 す）は 5 例で非開胸・胸骨上 $1 / 3$ 切除・喉頭食道 全摘術 (blunt dissection) が 4 例に，右開胸開 
表 1 頸胸境界部食道癌症例

\begin{tabular}{|c|c|c|c|c|c|c|c|}
\hline & 症例 & 性 & 年齢 & 占居部位 & 術＼cjkstart式 & 進行度 & 予 後 \\
\hline 1. & KY & M & 72 & $\mathrm{Ce}>\mathrm{Iu}$ & $\begin{array}{l}\text { 右開胸開腹食道要全摘 } \\
\text { 胸骨後食道胃吻合術 }\end{array}$ & $\underset{\substack{\mathrm{R} \\
\mathrm{n}_{0}}}{\mathrm{pm}}$ & 1年1力月死 \\
\hline 2. & TK & $\mathrm{F}$ & 74 & $\mathrm{Iu}>\mathrm{Ce}$ & $\begin{array}{c}\text { 胸壁前食道胃吻合術 } \\
\text { (Bypass術) }\end{array}$ & (食道気管瘦) & 25日死 \\
\hline 3. & $\mathrm{SH}$ & M & 59 & $\mathrm{Ce}>\mathrm{Iu}$ & $\begin{array}{c}\text { 非開胸, 胸骨柄切除, 喉頭食道全摘 } \\
\text { 後縦隔咽頭胃吻合术 }\end{array}$ & $\begin{array}{l}\mathrm{a}_{3} \\
\mathrm{n}_{0}\end{array}$ & 2 年 2 力月生 \\
\hline 4. & SY & M & 71 & $\mathrm{Ce}>\mathrm{Iu}$ & $\begin{array}{c}\text { 非開胸, 胸骨 } 1 / 3 \text { 切除, 喉頭食道全摘 } \\
\text { 後縦隔咽頭贯吻合逨 }\end{array}$ & $\begin{array}{l}\mathrm{n}_{2} \\
\mathrm{n}_{3}\end{array}$ & 15日死 \\
\hline 5. & KE & $\mathrm{F}$ & 52 & $\mathrm{Ce}>\mathrm{Iu}$ & 同 上 & $\begin{array}{l}\mathrm{a}_{3} \\
\mathrm{n}_{0}\end{array}$ & 1 年 4 力月死 \\
\hline 6 . & YI & M & 77 & $\mathrm{Iu}>\mathrm{Ce}$ & $\begin{array}{c}\text { 喉頭切除，胸壁前咽頭胃吻合術 } \\
\text { (Bypass衍) }\end{array}$ & $\begin{array}{l}\mathrm{A}_{3} \text { (気管) } \\
\mathrm{M}_{1} \text { (肺, 骨) }\end{array}$ & 3 力月死 \\
\hline 7. & IS & $\mathrm{F}$ & 66 & $\mathrm{Ce}>\mathrm{Iu}$ & $\begin{array}{c}\text { 非開胸, 胸骨 } 1 / 3 \text { 切除, 喉頭食道全摘 } \\
\text { 胸壁前咽頭骨吻合㭪 }\end{array}$ & $\begin{array}{c}\mathrm{a}_{3} \\
\mathrm{n}_{3} \\
\mathrm{M}_{1} \text { (肺, 骨) }\end{array}$ & 5 力月死 \\
\hline 8. & $\mathrm{KS}$ & M & 75 & $\mathrm{Iu}>\mathrm{Ce}$ & 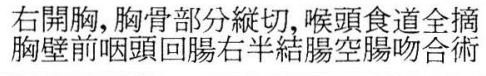 & $\begin{array}{l}\mathrm{a}_{2} \\
\mathrm{n}_{2}\end{array}$ & 7 力月生 \\
\hline
\end{tabular}

腹・食道垔全摘術が 1 例におこなおれた。I u > $\mathrm{Ce}$ は 3 例であるが, 切除されたのは 1 例のみ で, その術式注右開胸・胸骨部分䋛切開・喉頭 食道全摘術であった（表 1 )。

\section{III. 非開胸・胸骨上 $1 / 3$ 切除・喉頭食道全摘 術 (blunt dissection) とその手術成績}

\section{1. 食道切除とリンパ節郭清}

仰臥位で頸部から上胸部にかかるY字型皮膚 切開を加え, 頭側は内外頸動脈分岐部, 外側は 僧帽筋前縁までの両側 modified neck dissectionを抢こなう。次いで, 第 2 肋間より頭側の 胸骨, 肋軟骨および両鎖骨骨頭を切除し, 大動 脈弓より頭側の上縦隔リンパ節を郭清する。こ の時, 胸腺は浸潤がなければ温存する（図 1 )。 次に, 上腹部正中切開で開腹し, 胃管を作成 する。Vein stripperを用い, 肛側から口側に食 道を翻転抜去し, 喉頭と食道を摘出する。最後 に, 後縦隔経路または皮下に胃管を挙上し, 咽 頭と吻合する。

\section{2. 永久気管瘻造設}

気管孔の形成にあたっては種々の方法を試み た。

図 2 は大胸筋筋弁によって気管と大血管の間 を隔離した症例の模式図である。Y字型皮膚切 開の皮下を剥離, 大胸筋筋弁を作成し, 気管と 大動脈弓の間に筋弁を挿入した。図 3 はその術

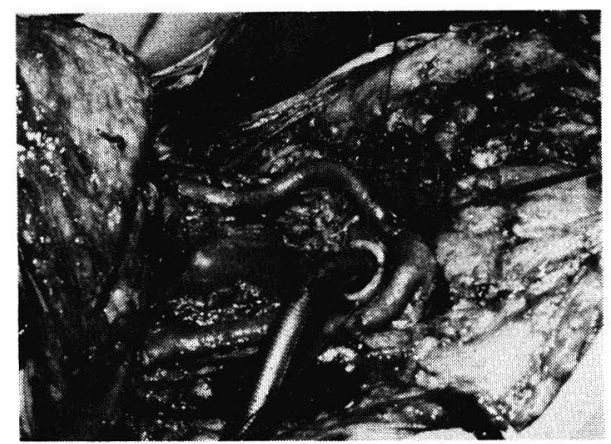

図 1 非開胸, 胸骨上 $1 / 3$ 切除, 喉頭食道全 摘術 (blunt dissection) の術中写真。 左が頭側，右が尾側である。喉頭と 食道が切除され，気管孔よりスパイラ ルチューブが挿管されている。両側の modified neck dissection と大動脈弓 より頭側の上縦隔りンパ節郭清がおこ なわれた。

中写真である。この症例は気管の剥離範囲が長 すぎたため，気管上部が壊死に陥り，膿瘍を形 成し, 腕頭動脈破裂のため術後15日目に死亡し た。筋弁での隔離が不充分であったため膿瘍が 波及し, 破裂したものと考えられた。

頸部の皮膚弁で気管孔を形成した症例もあ る。この症例では気管切開がなされていたため H型の皮膚切開をおこない, 下方の皮膚弁にU 字型の切開を加え, 気管膜様部を形成した（図 4)。しかし, 皮膚弁で形成された膜様部は支持 

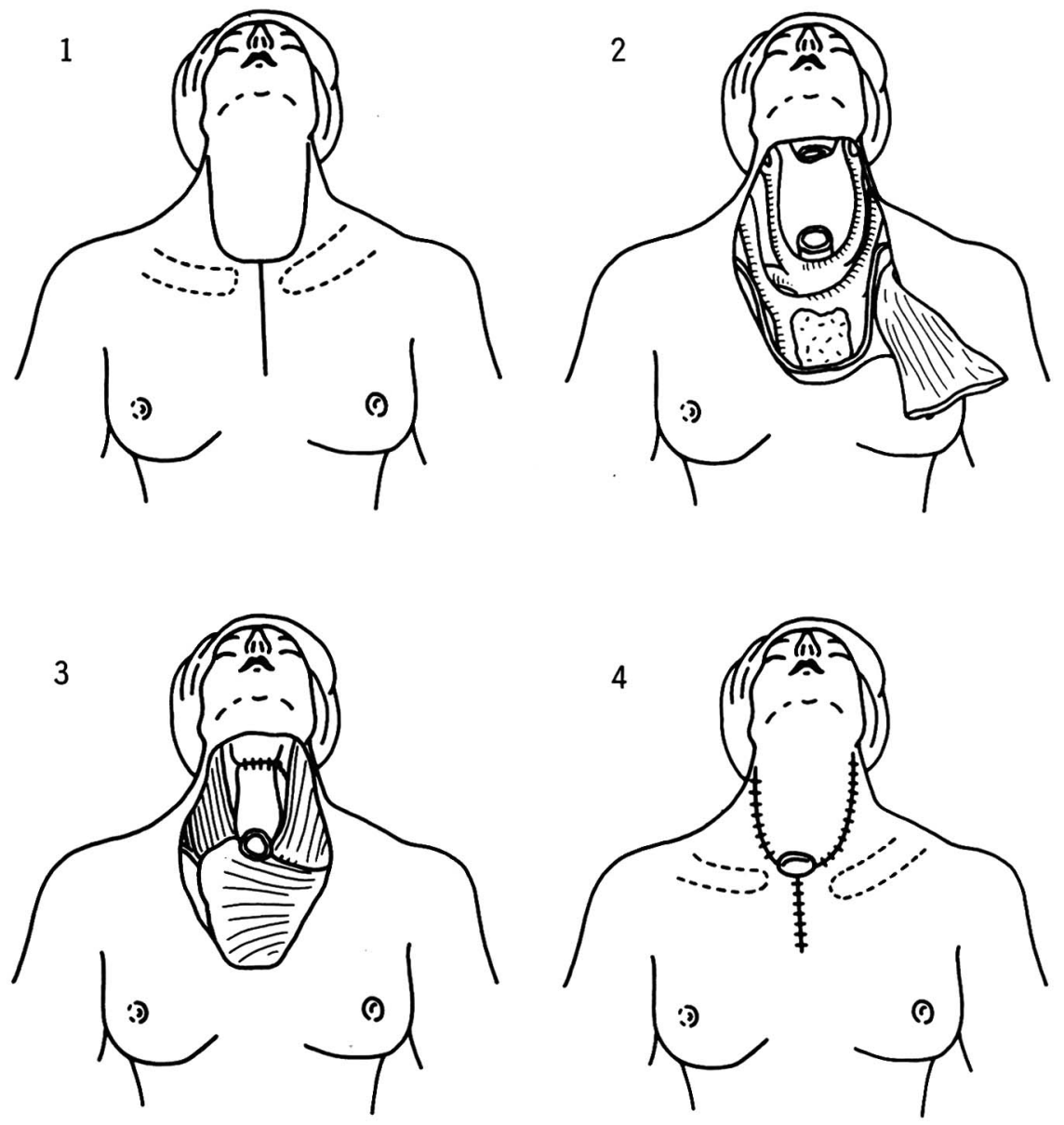

図 2 大胸筋有茥筋弁による気管と大血管の隔離。

$\mathrm{Y}$ 字型の皮切を加え(1), 皮下を剥離, 大胸筋有茎筋弁を作成する(2)。筋弁を気管 と大血管の間に挿入，両者を隔離する(3)。皮膚縫合(4)。

力に乏しく，気管孔の機能的狭窄をきたした。 また, 残った気管の長さが $3.5 \mathrm{~cm}$ と短かったた め気管支肺炎をくり返した。図 5 は創部の写真 で，気管孔にY字型の silicone stent が拥入さ れている。

大胸筋皮弁による気管孔の形成も経験した。 図 6 のように大胸筋皮弁 $(5 \times 10 \mathrm{c} \mathrm{m})$ を作成 し，筋皮弁の中央に切開を加え，その部と気管 断端を縫合した。術後, 筋皮弁は気管に牽引さ れて縦隔内に陥没し，筋皮弁による代用気管の ような形になった（図 7 )。

3. 手術成績

表 2 は本術式を施行した 4 例の臨床像をまと めたものである。術前に気管支鏡や CT で気管

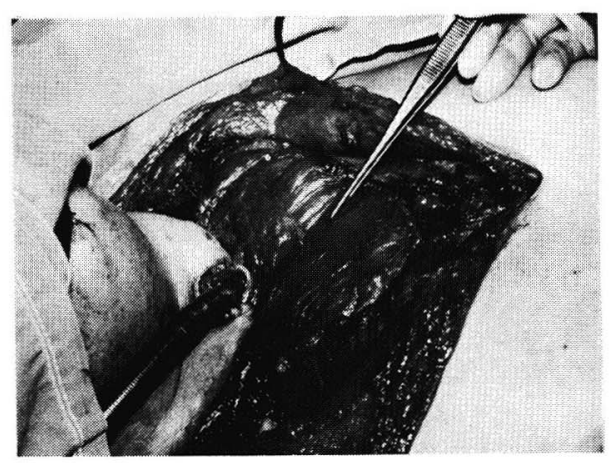

図 3 大胸筋有茎筋弁による気管と大血管の 隔離 (術中写真)。

左が頭側，右が尾側である。ピンセッ トが大胸筋筋弁を示す。気管孔にスパイ ラルチューブが挿管されている。 

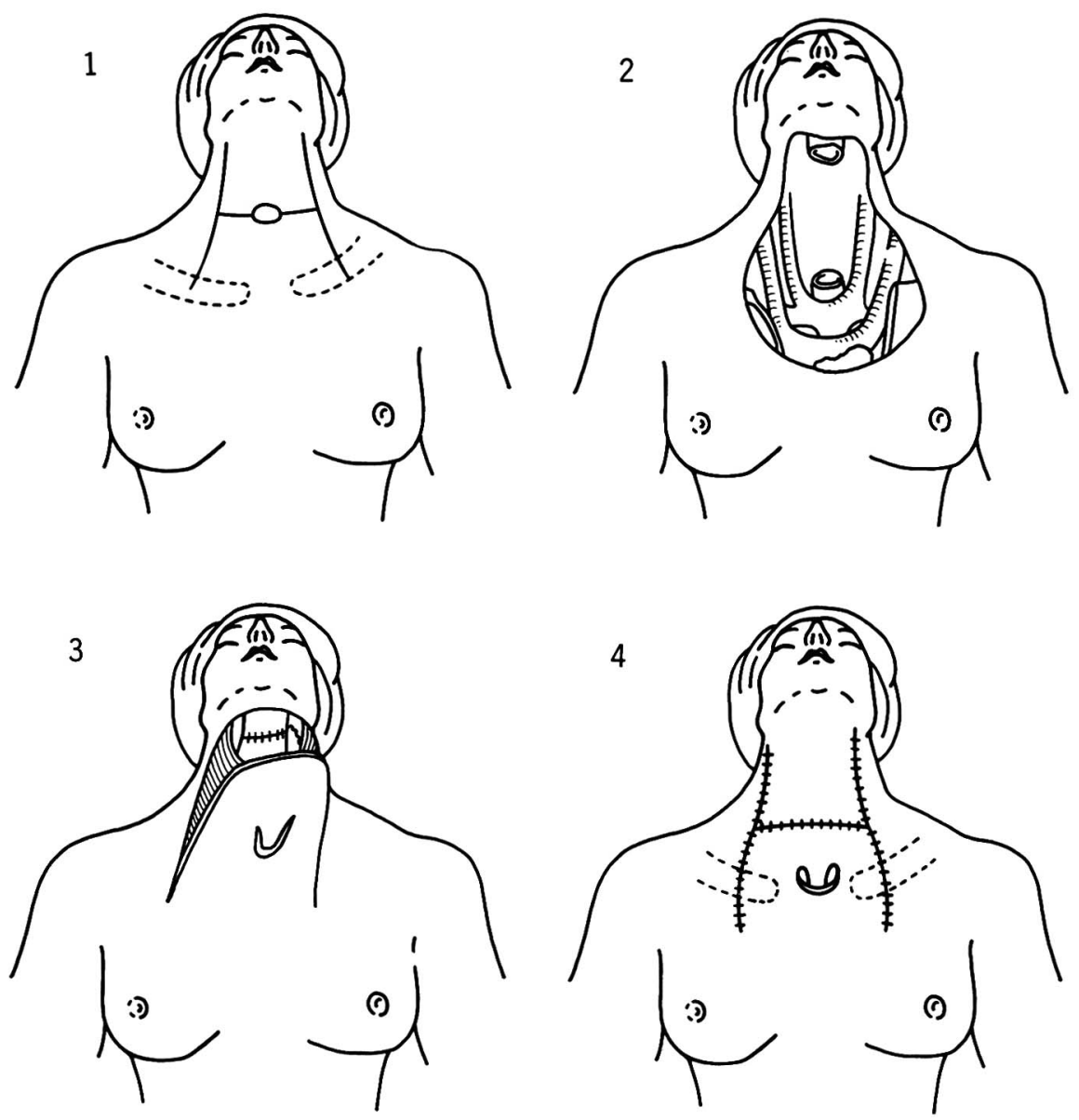

図 4 頸部皮弁による気管孔の形成。

気管切開がなされていたため, $\mathrm{H}$ 型の皮切をおこない(1), 喉頭食道を切除 した後(2), 下方の皮弁の中央にU字型の皮切を加え(3), それによって気管膜 様部を形成した(4)。

浸潤が予想された 3 例のうち 2 例に組織学的浸 潤がみとめられた。また，同様の検査所見から 浸潤なしと判定した 1 例でも肉眼的および組織 学的浸潤がみられ，結局，全例に喉頭と気管の 合併切除がおこなわれた。切除した気管の長さ は $5.5 \sim 8.0 \mathrm{~cm}$ で，残った気管の長さは $3.5 \sim 6.0 \mathrm{~cm}$ であった。

リンパ節転移は 4 例中 2 例にみられ，いずれ も $\mathrm{n}_{3}$ であった。郭清されたリンパ節個数は 34〜87個で，転移度は8.0\%(17/213)であった。 転移部位は No 101, No 102, No 106 であった。

重篤な合併症は気管壊死・腕頭動脈破裂, short trachea による難治性気管支肺炎, 気管あ るいは気管孔の狭窄などがみられ，3例が在院

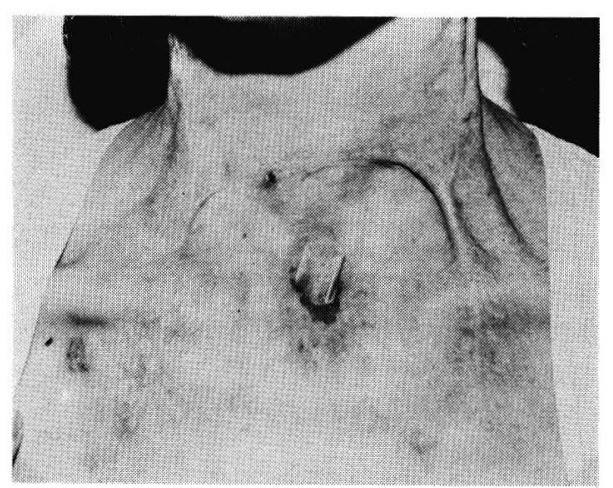

図 5 頸部皮弁による気管孔の形成（術後写 真)。

皮弁によって形成された膜様部が膨隆 し, 機能的狭窄をきたすため silicone stent が挿入されている。 

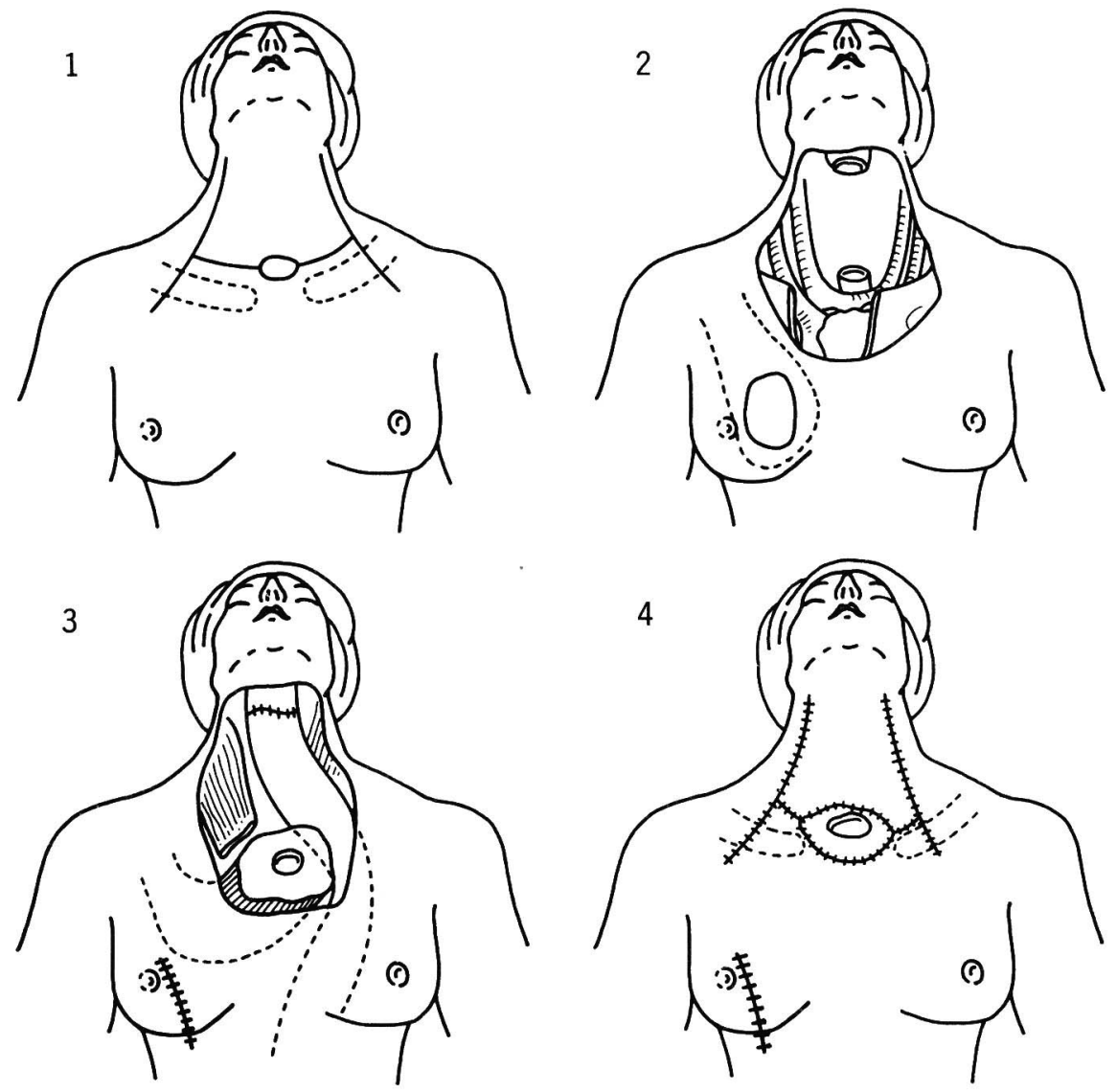

図 6 大胸筋筋皮弁による気管孔の形成。

気管切開のため $\mathrm{H}$ 型の皮切を加え(1), 喉頭食道を切除した後, 右大胸筋 筋皮弁を作成(2)。その中央部に孔をあけ，気管断端と縫合(3)，さらに，筋皮 弁を周囲の皮䖉と縫合して気管孔を形成する(4)。

死亡, うち 1 例が手術死亡となった。

予後をみると, 治癋切除 2 例のうち 1 例が 2 年 2 力月生存中であるが, 頸部に再発をみとめ ている。他の 1 例は上縦隔リンパ節再発による 大動脈気管瘻・出血のため 1 年 4 カ月で死亡し た。非治癒切除の 1 例は上縦隔りンパ節再発に よる上大静脈症候群，気管狭窄，肺炎のため 5 カ月で死亡した。再発は上緹隔とりわけ気管分 岐部あるいは気管気管支リンパ節転移が主で, 他に頸部再発や遠隔転移もみとめられた。

\section{IV. 右開胸・胸骨部分縦切開 ・喉頭食道 全摘術}

症例は75歳の男性, 7 力月前に他院で胃癌の ため根治的胃垔全摘術 (Billroth II 法)をうけて

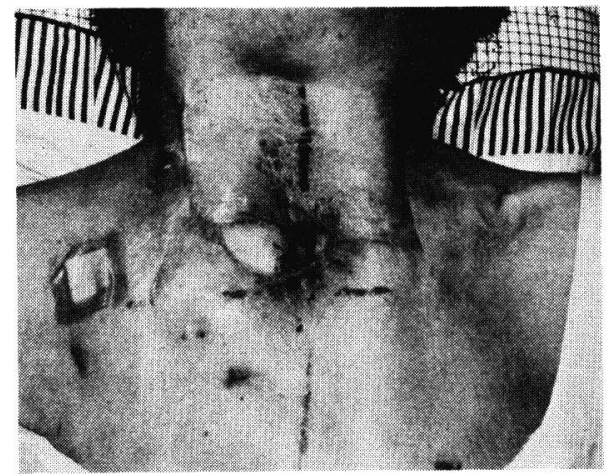

図 7 大胸筋筋皮弁による気管孔の形成（術 後写真)。

筋皮弁が気管とともに縦隔内に陥没 し，代用気管のような形になった。筋皮 弁の場合は支持力が強く, stent は不要で あった。 
表 2 頸胸境界部食道癌に対する非開胸・胸骨上 $1 / 3$ 切除・喉頭食道全摘術 (blunt dissection) 症例

\begin{tabular}{|c|c|c|c|c|c|c|c|c|c|}
\hline & 症例 & $\begin{array}{l}\text { 気管浸潤の } \\
\text { 術 前 診断 }\end{array}$ & $\begin{array}{r}\text { X.P上 } \\
\text { 切除気管長 }\end{array}$ & 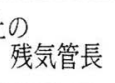 & 病理所見 & 根治性 & 合 併 症 & 再 発 & 予 後 \\
\hline 1. & $\mathrm{SH}$ & - & $\begin{array}{l}7.5 \mathrm{~cm} \\
\text { (不明) }\end{array}$ & $5.0 \mathrm{~cm}$ & $\begin{array}{l}\mathrm{a}_{3}(\text { 気管 }) \\
\mathrm{n}_{0}(0 / 57)\end{array}$ & $\mathrm{C}$ III & $\begin{array}{l}\text { 両胸水貯留, 気管孔狭究 } \\
\text { minor leakage,吻合部狭愍 }\end{array}$ & 頸部リンパ節 & $\begin{array}{l}\text { 2年2力月生 } \\
\text { (再発生存) }\end{array}$ \\
\hline 2. & SY & 十気管支鏡 & $\begin{array}{l}6.0 \\
(7 \text { rings })\end{array}$ & 6.0 & $\begin{array}{l}\mathrm{a}_{2} \\
\mathrm{n}_{3}(4 / 87)\end{array}$ & C I & $\begin{array}{c}\text { 両胸水貯留 } \\
\text { 気管壊死, 腕頭動脈破裂 }\end{array}$ & - & 15日術死 \\
\hline 3. & $\mathrm{KE}$ & 十気管支鏡 & $\begin{array}{l}8.0 \\
\text { (10 rings) }\end{array}$ & 3.5 & $\begin{array}{l}\mathrm{a}_{3}(\text { 気管 }) \\
\mathrm{n}_{0}(0 / 35)\end{array}$ & C III & $\begin{array}{l}\text { 両胸水貯留, 創感染 } \\
\text { 気管狭窄，気管支肺炎 }\end{array}$ & 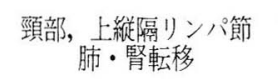 & 1 年 4 力月死 \\
\hline 4. & IS & $+\mathrm{CT}$ & $\begin{array}{l}5.5 \\
\text { (10 rings) }\end{array}$ & 6.0 & $\begin{array}{l}a_{3}(\text { 気管 }) \\
n_{3}(13 / 34)\end{array}$ & $\mathrm{C}_{0}$ & $\begin{array}{c}\text { 両胸水貯留 } \\
\text { 爻管狭窄 }\end{array}$ & $\begin{array}{l}\text { 頸部, 上絴隔リンパ節 } \\
\text { 気管断端, 肺・骨・転移 }\end{array}$ & 5 力月死 \\
\hline
\end{tabular}

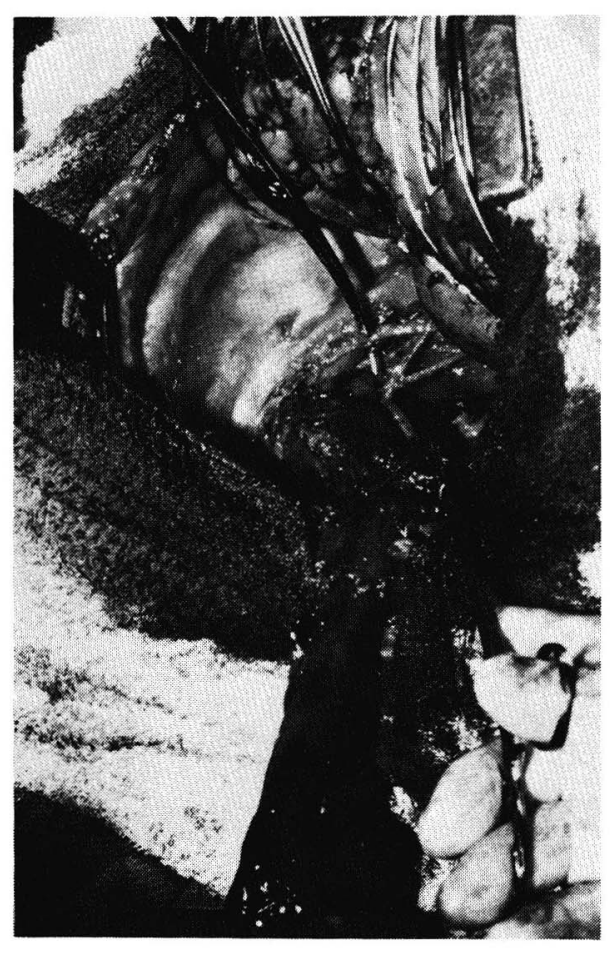

図 8 右開胸, 胸骨部分縦切開, 喉頭食道全 摘術 (術中写真)。

右第 4 助間開胸で，気管周囲のリンパ 節郭清をおこなった。食道は肛側で切断 され，創外に引き出されている。上方の 鉗子が迷走神経を，下方の鉗子が気管支 動脈を示している。

いた。癌の占居部位は $\mathrm{Iu}>\mathrm{Ce}$, 長径 $10.5 \mathrm{~cm}$, 腫瘤型で, 気管支鏡, CT 検査で癌腫の気管への 浸潤がつよく示唆された。

昭和 59 年 10 月 17 日，第 1 期手術として，右開 胸・胸骨部分縦切開, 喉頭食道全摘術 - 広背筋 有茎筋弁による気管被覆・永久気管瘦・咽頭㿉,

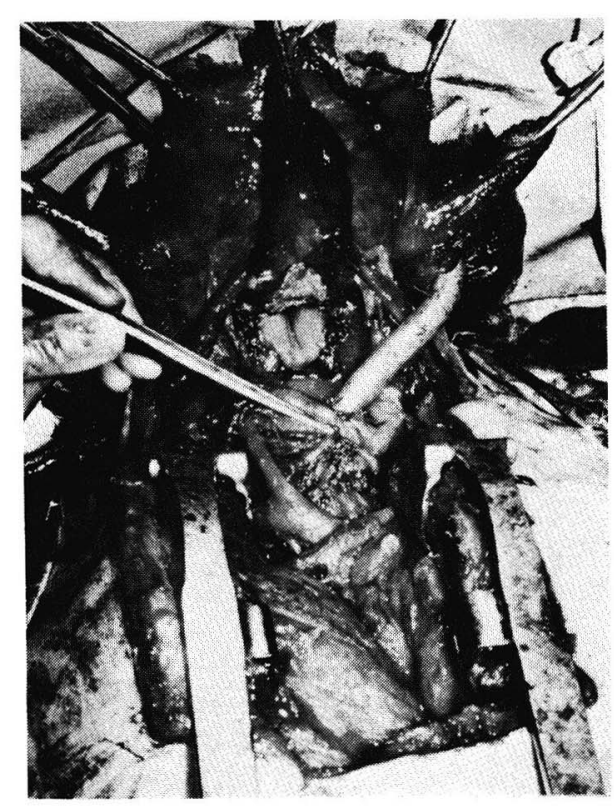

図 9 右開胸, 胸骨部分緃切開, 喉頭食道全 摘術 (術中写真)。

胸骨部分綐切開で頸部上緃隔のリンパ 節を郭清し，喉頭食道を切除した後，広 背筋有茎筋弁を胸腔内より頸部に引き出 し, 気管周囲を被覆, 大血管より隔離し た。

胃瘻造設術をおこなった。

右側臥位とし，まず開胸に先立ち，幅 $10 \mathrm{~cm}$, 長さ $30 \mathrm{~cm}$ の広背筋有茎筋弁を作成した後, 右 第 4 肋間で開胸, 右気管支動脈を温存しつつ胸腔 内リンパ節を郭清し, 食道を横隔膜上で切断, 口側に剥離をすすめた (図 8 )。癌腫の下半分は 縦隔内にあり, 気管と強固に癒着していたが, 剥離可能であった。しかし, 右横隔膜神経, 右 迷走神経, 左反回神経, 胸管には肉眼的に浸潤 


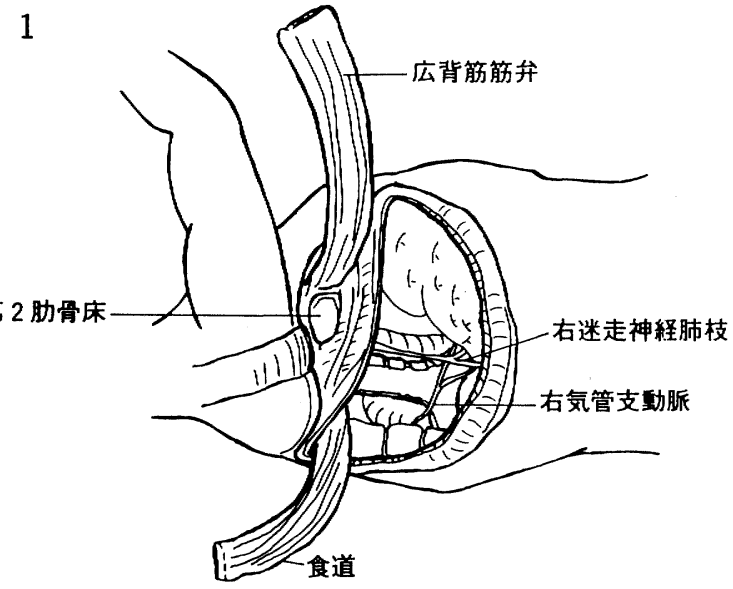

3

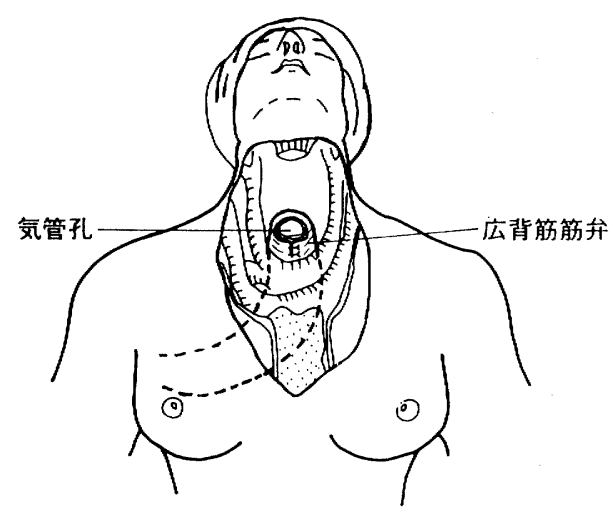

2

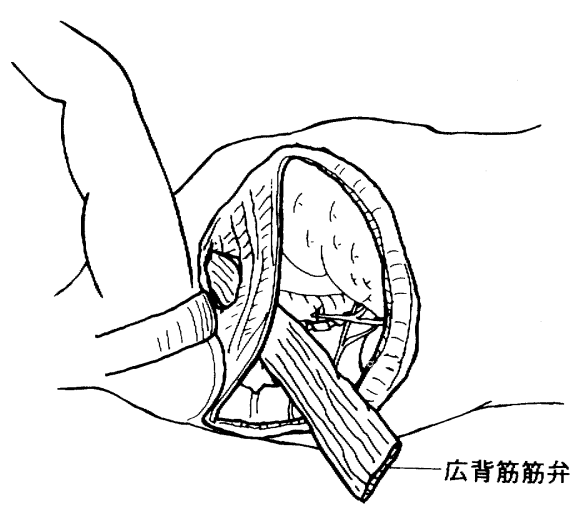

4

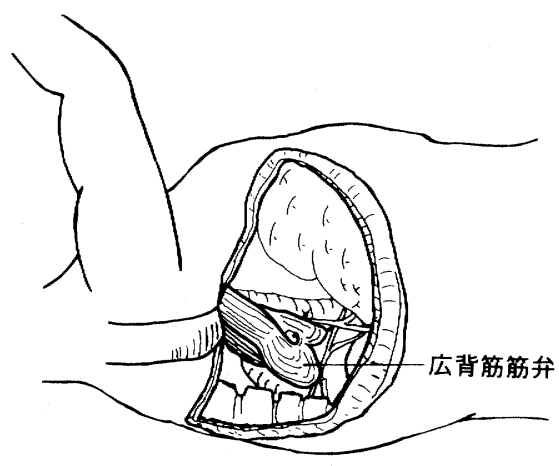

図10 広背筋有茎筋弁による気管の被覆。

開胸に先立ち幅 $10 \mathrm{~cm}$, 長さ $30 \mathrm{~cm}$ の広背筋有茎筋弁を作成, 第 2 肋骨を $5 \mathrm{~cm}$ 切除し, 筋弁の插入孔をつくつた。ついで, 右第 4 肋間で開胸, 横隔膜上で食道を切断, 口側に向 つて剝離しつつ気管周囲を郭清した。この時, 右気管支動脈と右迷走神経肺枝 (後に切 断）を温存した(1)。広背筋筋弁を胸腔内に挿入し(2), 仮閉胸した。頸部上縦隔の郭清, 喉 頭食道切除が終ったところで, 広背筋筋弁を頸部に引き出し, 気管の周囲を被覆した(3)。 再開胸し，筋弁で縦隔内気管の周囲をできるだけ被覆した(4)。

がみとめられ，合併切除した。ここで，第 2 助 骨床より広背筋有茎筋弁を胸腔内に插入し, 仮 閉胸した。

体位を変換, 仰臥位とし, 頸部から胸部にか けてY字型の皮膚切開をおこない, 胸骨を第 4 肋間の位置まで縦切開し, さらに横切開を加え た。腕頭動静脈, 左右総頸動静脈, 右鎖骨下動 静脈の周囲を郭清し, 食道を頸部に引き出し, 癌腫を気管から剥離しつつ気管周囲を郭清し た。甲状腺上極の高さで気管を, 喉頭蓋の高さ で咽頭を切断し, 喉頭と食道を摘出した。

ついで, 胸腔内の広背筋筋弁を頸部に引き出
し, 頸部気管の周囲を被覆し, 大血管と完全に 隔離した(図 9)。さらに, 咽頭と永久気管瘻を 作成した。

再び右側臥位として開胸し, 縦隔内気管の周 囲をできるだけ広背筋筋弁で分岐部近くまで被 覆し，手術を終了した（図10）。

術後 1 週頃より adult respiratory distress syndrome(以下, ARDS と略す)を併発したが, 回復した。

約 2 力月後の昭和 59 年 12 月 19 日, 第 2 期手術 をおこなった。術式は胸壁前咽頭空腸間・回腸 右半結腸間置術・血行再建術であった。 


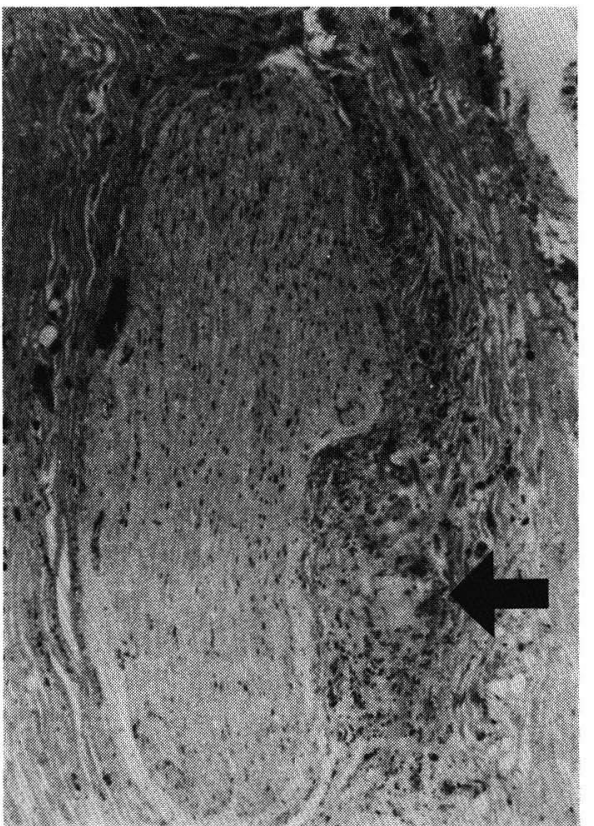

図11術中に摘出された左反回神経の病理組 織像。

矢印の部分で, perineural invasion がみとめられる。

頸部から下腹部に至る正中切開で開腹，中結 腸動静脈を荎とする回腸右半結腸を胸壁前に頸 部まで挙上した。この時, 回腸と盲腸付近が循 環障害に陥つたため, 右内胸動脈と中結腸動脈 を吻合, ついで, 大伏在静脈を約 $10 \mathrm{~cm}$ 切除し, 左橈側皮静脈根部と中結腸静脈間に間置した。 その結果, 循環障害は改善し, 咽頭と回腸, 結 腸と空腸を吻合して手術を終了した。

術後, 再び肺炎を併発したが回復, 縫合不全 もなく， 7 力月後の現在，術後照射施行中であ る。

切除標本の組織学的所見は, いわゆる癌肉腫 （食道の偽肉腫）で， $\mathrm{a}_{2} ， \mathrm{n}_{2}(5 / 90)$, stage III, RIII, CII で，No 105，No 106 (気管前および左 最上部リンパ節）に転移があり，また，切除し た左反回神経に perineural invasionがみとめ られた（図11）。

\section{V. 考察}

頸胸境界部食道癌の治療成績は不良で2), 術式 もまだ標準的なものはない。その理由は癌の部 位的特性から気管浸潤例が多く，また，リンパ
節転移が頸部と胸部にわたるため癌の根治切除 が困難な上，拡大合併切除をおこなった場合の 手術侵襲や術後の機能障害が過大となるためと 考えられる。

教室では頸胸境界部食道癌で，とくに気管浸 潤を有する Ce > Iu 症例に対し，できるだけ癌 の根治切除をめざし，しかも，侵襲の少ない術 式として, 非開胸・胸骨上 $1 / 3$ 切除を加えた喉頭 食道全摘術 (blunt dissection) ${ }^{316)}$ を選択してき た。この術式では気管の切除範囲が長く, リン パ節郭清もかなり徹底しておこなえたが,また， いくつかの問題点のあることも判明した。

以下，それら問題点の検討をおこなう。

まず，第 1 の問題点として，リンパ節郭清範 囲が不充分なことがあげられる。この術式では 頸部と大動脈弓より頭側の上緹隔上部リンパ節 (No 106 上)の郭清は充分おこなえたが, 胸腔内 のとくに気管気管支リンパ節 (No 106 下) や気 管分岐部リンパ節（No 107）の郭清は不可能で あり, 術後のリンパ節再発もその部位に多かっ た。

図12は頸胸境界部食道癌で, 比較的充分にリ ンパ節郭清ができたと考えられる 5 例のリンパ 節転移状況を，手術時と再発時（剖検時）で対 比してみたものであるが，これによると，頸部 と上緹隔の全てのリンパ節 (No 100～107) は術 中の転移または再発の可能性があり，郭清を扔 ろそかにできないことが示されている。したが って, Iu > Ce, Ce > Iu のいずれの場合も頸胸 部にかかった食道癌は全て開胸による胸腔内リ ンパ節郭清が必要と考えられる。

磯野ら ${ }^{7)}$ や遠藤 ${ }^{8)}$ は頸胸境界部食道癌の術 式として, Iu > Ce, Iu = Ce は開胸と胸緃切, $\mathrm{Ce}>\mathrm{Iu}$ は胸縦切または胸骨切除と開胸または blunt dissection (非開胸) による到達法が適当 であろうと述べているが，著者らは頸胸境界部 にかかる症例は全て開胸と胸縦切または胸骨切 除を組み合わせた到達法を選択すべきで, blunt dissection の適応は Ce に限局し，しかも，比較 的早期のものに限られるのではないかと考えて いる。

また，安藤ら ${ }^{4)}$ は, door open 法による到達 法をおこなっているが，この術式では同一視野 内に頸部と上縦隔が展開され，胸腔内リンパ節 
も郭清でき, 体位変換を必要としない 優れた術式と考えられるが，気管左側 のリンパ節郭清がどの程度可能か, 多 少疑問の残るところである。

第 2 の問題点は気管の壊死や穿孔で ある。気管周囲を広範に郭清し，また， 癌腫を気管膜様部から強引に剥離する と，術後に気管の虚血による壊死や穿 孔を扔こし，縦隔膿瘍から大血管の破 裂をきたす危険がある ${ }^{3)}$ 。これに対し， 著者らは気管の血流障害を防止するの みならず，たと光，気管壊死や穿孔が 発生しても大血管への膿瘍波及をくい 止めようと考え，筋弁によって気管や 大血管を被覆した。しかし, 筋弁を頸 部から插入しただけでは気管の完全な 被覆は困難で，大血管への膿演波及を 防止できないことを経験した。そこで， 筋弁を第 2 助骨床上り胸腔内に挿入 し, 縦隔側から頸部に筋弁を引き出し, 気管の周囲を被覆し, 大血管から完全 に隔離した ${ }^{9110)}$ 。この場合, 開胸例では 広背筋を, 非開胸例では大胸筋を用い, ほほ同じ術式で気管を被覆することが 可能であった ${ }^{111}$ 。

さらに，気管壊死の防止には開胸例 では右気管支動脈を積極的に温存し, また，消化管の再建にあたつては後縦 隔に胃管を挙上し, 膜様部を支持し, 血流障害や穿孔を防止することも重要 であろう。また，気管孔を筋皮弁で形 成し，気管の緊張を減少することも血 流障害を防ぐ一法と考えている。そし

て，もし気管壊死が発生した場合にはただちに 壊死部を切除し，皮膚と再縫合することが膿瘍 の拡大と大血管破裂を防止する上で重要である3”。

第 3 の問題点として, short tracheaによる合 併症 (気管支肺炎，気管孔狭窄）があげられる。 胸骨を切除すると，気管浸潤例に対してもかな り広範な気管切除が可能である。最も長く切除 した症例では気管分岐部から $3.5 \mathrm{~cm}$ まで切除 しえた。しかし，この症例では short tracheaに よる気管支肺炎を繰返し，結局，在院死亡とな つた。そこで，次の症例で大胸筋皮弁により気

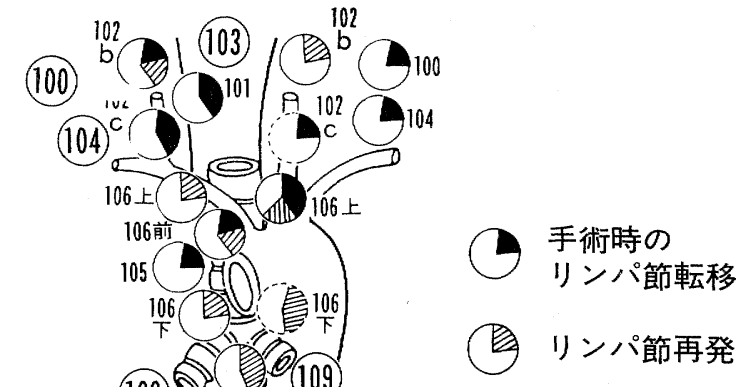

手術時リンパ節転移率 $60 \%(3 / 5)$

手術時転移十再発 $100 \%(5 / 5)$
図12 頸胸境界部食道癌（5例）のリンパ節転移。

手術時と再発時を比較すると, 手術時は頸部と大動脈弓 より頭側の上䋛隔に多く, 再発は大動脈弓より尾側の上縦 隔に多かった。頸胸境界部食道癌のリンパ節郭清は No 100〜No 107 の頸部上縦隔リンパ節に重点的におこなわれ るべきである。

管孔を形成したところ ${ }^{12}$ ，それが縦隔内に引き 込まれ，代用気管のような形になることを経験 した。したがって，残った気管の長さに応じ， 大胸筋皮弁の大きさや形を工夫すれば，この問 題はある程度解決できるのではないかと考えて いる。気管孔を形成する場合，皮膚弁 ${ }^{3 / 6)}$ は支持 力が弱く, stentを挿入しないと気管孔が狭く なる可能性があり，不適当と考えられる。

第 4 の問題は郭清範囲内の再発である。Modified neck dissectionを抢こなった 4 例のうち 3 例（1 例は術死）に郭清範囲内の再発がみと 
められた。その原因の 1 つとして, リンパ節転 移の遺残の他に, 神経鞘や血管鞘のリンパ管侵 襲の増殖も考えられる。このような癌の遺残は 神経や血管を en bloc に切除しない限り防止す ることは不可能であり, 頸部のように神経, 血 管の豊富な部位では術後の再発の可能性はかな り高いと考えねばならない。したがって, 術後 の予防的照射はこのような再発を防止する上 で，ぜひ必要である。

第 5 に, 喉頭を切除するか温存するかの問題 がある。著者らは初期の症例において術前照射 をおこなったところかなり有効であったので (照射後の深達度は固有筋層まで, すなわち R$\mathrm{pm})$, 喉頭を温存したところ, 頸部気管の局所再 発をきたし， 1 年 1 力月で失った症例を経験し た。また, 掛川ら ${ }^{2)}$ は喉頭を温存したため, 反回 神経麻痺により満足すべき経口摂取をえられな かった症例を経験したと述べている。一方，葛 西ら ${ }^{3)}$ は喉頭温存例が喉頭切除例に比べ直死が 少なく, 遠隔成績も良好なことから, 適応を選 べば喉頭温存は必ずしも予後不良因子ではない と述べている。

頸胸境界部癌の場合, とくに左側の反回神経 は気管および食道癌腫のごく近傍にあり, 直接 浸潤をうける可能性が高く，たとえ直接浸潤が なくても, 神経鞘への脈管侵襲がみられること がある。また, この付近のリンパ節郭清は最も 重点的に扢こなわなければならず, 左反回神経 の切除や損傷を避けることはかなり困難と考元 られる。したがって, 術中右反回神経を損傷し, 結果的に両側の反回神経麻痺が強く予想される 症例では, たとえ気管浸潤がなくても喉頭を切 除した方が無難であろう。一方，あきらかに片 方の, とくに右反回神経の温存が確実であり, 気管への浸潤がないと判断されれば喉頭を温存 してょく, 片側だけの声帯麻痺に対しては silicone 注入などで対処することができる。

喉頭食道全摘後の発声は, 喉頭癌などで喉頭 切除のみをおこなった患者に比べ容易でなく, このような患者の発声についてはまだ解決すべ き多くの問題が残されている。

以上述べたような問題点に対処する術式のひ とつとして, 右開胸・胸骨部分縦切開による喉頭 食道全摘術を試みた。この術式では Botalloり
ンパ節など一部のリンパ節を除く頸部上縦隔の ほぼ全域のリンパ節郭清が可能であると考えら れる。また，右気管支動脈や胸腺を温存し，さ らに広背筋有茎筋弁で気管を被覆することによ り，気管の壊死防止をはかることができる。さ らに，もし気管膜様部の合併切除が必要になっ た場合は，切除部を筋弁で補填したり，また， 胸骨上部を切除することによって縦隔気管を引 き出し，大胸筋皮弁で気管孔を形成することも 可能で，種々の状況に応じた術式を選択できる 点で優れた方法であろうと考えている。

\section{IV 。まとめ}

気管浸潤を有する頸胸境界部食道癌に対し, 胸骨上 $1 / 3$ 切除, 喉頭食道全摘術 (blunt dissection)を 4 例経験した。この術式では胸腔内リン パ節再発, 気管壊死, short trachea による気管 支肺炎, 気管孔狭窄など種々の問題点があり, 術式の再検討をせまられた。そこで, 右開胸・ 胸骨部分䋛切開 - 喉頭食道全摘術に広背筋有茎 筋弁で気管を被覆するなどいくつかの改良を加 えた術式を考案し, 臨床で試みた。この術式の 特徴として,

(1)右開胸で上縦隔下半部の郭清と, 胸縦切に よって頸部と上縦隔上半部の郭清が可能となる

(2)気管の血流を保存するため，右気管支動脈 を温存し, 広背筋筋弁で気管を被覆し壊死を防 止する方法を加える

(3)広背筋筋弁で気管と大血管を完全に隔離 し，気管壊死が発生しても，大血管への波及を 防止しうる

などがあげられる。さらに，気管膜様部の合併 切除が必要な場合, 容易に広背筋で補填するこ とができ，また，気管孔の形成が必要な場合， 胸骨上部を切除し，大胸筋皮弁を使用すること も可能であり，きわめて有用な術式であるとい える。

\section{引用文献}

1) Waddel, W.R. et al.: Anterior approach to carcinoma of the superior mediastinal and cervical segments of the esophagus. J. Thorac. Surg., 33 : 663-669, 1957.

2) 掛川暉夫 - 他: 頸胸境界部食道癌の外科治療, 臨外, 29:739-742, 1974.

3 ）加藤抱一・他：頸胸境界部食道がんに対する食 
道抜去術及び Grillo の手術の応用, 日胸外会誌, 31:706-707, 1983.

4 ）安藤暢敏・他：前方経路 (Door open 法による 頸胸境界部食道癌の切除郭清術, 日胸外会誌, $31: 710-711,1983$.

5) Orringer, M.B. : Partial median sternotomy: Anterior approach to the upper esophagus. J. Thorac. Cardiovasc. Surg., 87 : 124-129, 1984.

6 ) Grillo, H.C.: Terminal or mural tracheostomy in the anterior mediastinum. J. Thorac. Cardiovasc. Surg., 51: 422-427, 1966.

7 ) 磯野可一・他：頸胸境界部食道癌の切除・再建, 日胸外会誌，31：712-714，1983.

8 ）遠藤光夫 - 他：頸胸境界部食道癌の切除・再建, 日胸外会誌, $31 ： 716-718,1983$.

9 ）川原英之・他：食道癌の気管また注気管膜様部 合併切除例にお打治背筋有茎筋弁補強術式の 有用性, 日外会誌, 85：300-306，1984。

10）川原英之・他：広背筋有茎筋弁を応用した胸部
食道癌における気管合併切除術の 1 例, 日胸外会 誌, $32 ： 1090-1095,1984$.

11）溝口義人 - 他 : 腕頭動脈 -上大静脈 - 気管を合 併切除した胸腺癌の 1 手術例, 日臨外会誌, 46 (臨 増) : 30,1985 .

12) Terz, J.J. et al. : Results of extended resection of tumors involving the cervical part of the trachea. Surg. Gynec. Obstet., 151 : 491-496, 1980.

13）葛西森夫・他：頸部食道癌の再建術式の検討一 特に有茎空腸片による術式一, 消化器外科, 6 ： 555-560, 1983.

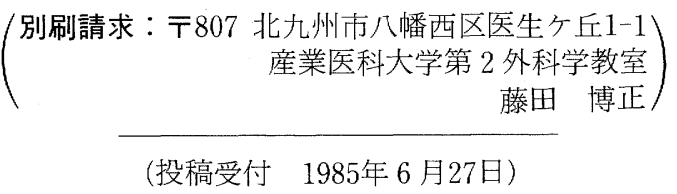

